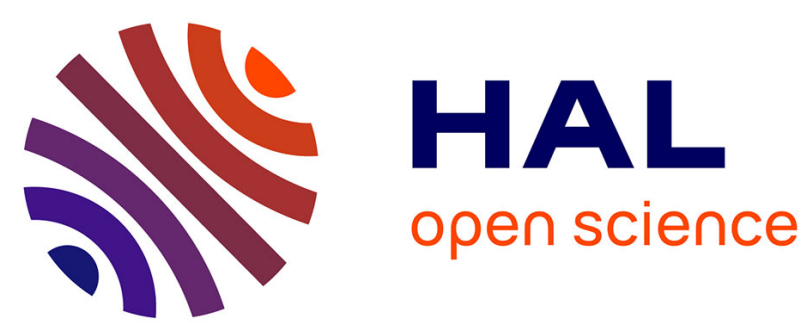

\title{
Evaluation of a non cystatin-C-based novel algorithm to calculate individual glomerular filtration rate in cancer patients receiving carboplatin
}

Karin Holweger, Hans-Peter Lipp, Jos H. Beijnen, Carsten Bokemeyer, Joerg Thomas Hartmann

\section{To cite this version:}

Karin Holweger, Hans-Peter Lipp, Jos H. Beijnen, Carsten Bokemeyer, Joerg Thomas Hartmann. Evaluation of a non cystatin-C-based novel algorithm to calculate individual glomerular filtration rate in cancer patients receiving carboplatin. Cancer Chemotherapy and Pharmacology, 2010, 68 (3), pp.693-701. 10.1007/s00280-010-1537-0 . hal-00649064

\section{HAL Id: hal-00649064 https://hal.science/hal-00649064}

Submitted on 7 Dec 2011

HAL is a multi-disciplinary open access archive for the deposit and dissemination of scientific research documents, whether they are published or not. The documents may come from teaching and research institutions in France or abroad, or from public or private research centers.
L'archive ouverte pluridisciplinaire HAL, est destinée au dépôt et à la diffusion de documents scientifiques de niveau recherche, publiés ou non, émanant des établissements d'enseignement et de recherche français ou étrangers, des laboratoires publics ou privés. 


\section{Evaluation of a non cystatin-C-based novel algorithm to calculate individual glomerular filtration rate in cancer patients receiving carboplatin}

Karin Holweger, PhD student, Pharmacist, Department of Hospital Pharmacy, Roentgenweg 9, 72076 Tuebingen, Germany

Hans-Peter Lipp, PhD, Director of Department of Hospital Pharmacy, Roentgenweg 9, 72076 Tuebingen, Germany

Jos H Beijnen, PhD, Department of Pharmacy, Slotervaart Hospital Amsterdam, Louwesweg 6, 1066 EC Amsterdam, The Netherlands

Carsten Bokemeyer, MD, Professor of Internal Medicine-Oncology-Hematology, University Medical Center Eppendorf, Martinistr. 52, 20251 Hamburg, Germany Joerg Thomas Hartmann, MD, Professor of Internal Medicine-OncologyHematology, Comprehensive Cancer Center North, Christian-AlbrechtUniversity of Kiel, Arnold-Heller-Str. 3, 24105 Kiel, Germany

Correspondence: Mrs Karin Holweger, Department of Hospital Pharmacy, Roentgenweg 9, 72076 Tuebingen, Germany, fax 49 7071-29-5050, phone 49 7071-2982278, e-mail karin.holweger@med.uni-tuebingen.de 


\section{Abstract}

Purpose: The purpose of this study was to determine the potential utility of a novel algorithm to calculate individual GFR values in cancer patients. Based on carboplatin AUC measurements the algorithm-based values were compared with results related to other routinely used equations.

Methods: The association between measured and predicted carboplatin AUC was examined by the Bland-Altman analysis to determine bias and precision. Based on the Calvert formula, GFR values assessed by different routes of calculation including the novel algorithm were compared with each other in individual patients.

Results: The mean absolute administered carboplatin dose was $498 \mathrm{mg}$ and the mean measured carboplatin AUC $5.8 \mathrm{mg} / \mathrm{ml} \times$ min. Compared to the novel algorithm, the degree of bias to calculate carboplatin AUC was greater with the Cockcroft-Gault, Chatelut, Hoek and Schmitt formula which includes cystatin C as a parameter. In selected patients, algorithm-based GFR values were closer to GFR according to the Calvert formula than results of other equations, including the Jeliffe formula.

Conclusion: These results suggest that the concept of a non cystatin C-based novel algorithm including three different formulas rather than one single equation may improve accurate estimation of GFR over a broad range of constitutive values, including patients with low constitutive renal function as well as overweight patients.

Key words: Novel algorithm - carboplatin AUC - glomerular filtration rate cystatin C 


\section{Introduction}

The anticancer drug carboplatin belongs to a well-defined group of agents which is highly excreted in unchanged form via glomerular filtration [1]. Based on its narrow therapeutic window and the well described correlation between AUC values and clinical efficacy as well as myelotoxicity [2-4], the Calvert formula $($ dose $=$ target $A U C \times(G F R+25))$ has been established to improve the individualization of carboplatin-containing chemotherapy based on renal function instead of body surface area [5]. In this regard, accurate assessment of individual glomerular filtration rate (GFR) appears to be mandatory if theoretically calculated and clinically realized AUC values should be close to each other. However, in spite of multiple publications which have suggested that the probably best fitted formula might be available to calculate individual renal function, the results are still somewhat disappointing based on significant over- and underestimation of GFR [6-8].

Very recently, we proposed a novel algorithm to be beneficial compared to other available mathematical calculation strategies [9-11] because three formulas [1113] rather than one single formula may reflect the real situation of a broad GFR range more closely (figure 1) [14]. In order to prove the validity of this algorithm in clinical practice, we determined carboplatin-AUC values based on a limited sampling method by atomic absorption spectrometry (AAS) and compared the measured carboplatin AUC with predictive values calculated via different GFR ways substituted into the Calvert formula (Table 1). We include the broadly accepted Jelliffe- and Cockcroft-Gault formula [9,10], the Hoek formula $[15,16]$ based on cystatin $\mathrm{C}$ measurements, as well as endogenous $\mathrm{CrCl}$ measurements based on 24-hour-urine collection and the novel algorithm [14]. In addition, in individual cases, for example overweight patients or renal 
insufficiency, we compared calculated GFR values with each other in regard to accuracy, over- and underestimation.

\section{Methods:}

Enrollement of patients:

We considered 40 patients and have to excluded 11. The reasons are: infusion duration longer than one hour ( $>1$ hour \pm 5 minutes), wrong urine collection, dead between written informt consent and starting therapy, carboplatin AUC 6 instead of AUC 5, adverse effect of carboplatin, interruption of chemotherapy and wrong or missed blood sampling time points. Therefore, the prospective analysis included 29 adult caucasian cancer patients with an underlying stable renal function who were scheduled to receive a carboplatin 1-h infusion with carboplatin AUC 5. Exclusion criteria were dialysis, anuria, renal tumor, bone marrow infiltration and hydration. All patients provided written informed consent. The study was performed after approval of the local institutional ethic committee review board of the Eberhard-Karls University of Tuebingen and was in accordance with the guidelines of the Declaration of Helsinki.

\section{Pharmakokinetic assessment and calculation of carboplatin AUC}

For the determination of carboplatin (free platinum) a limited sampling strategy published by Sorensen et al. was utilized [17]. Infusion duration and sampling time points were strictly controlled. Table 2 shows the actual duration of infusion of carboplatin and sampling time points of each patient. Blood samples $(5 \mathrm{~mL}$ in EDTA collection tubes) were obtained before, at $0.25 \mathrm{~h}$ and $2.75 \mathrm{~h}$ after the beginning of the carboplatin 1-h infusion. All of the samples were centrifuged at $3.000 \mathrm{rpm}$ for $10 \mathrm{~min}$ at $20^{\circ} \mathrm{C}$ within $15 \mathrm{~min}$ after collection. The ultrafiltrate plasma fraction representing the non-protein bound active carboplatin fraction, 
was prepared using the Amicon micropartition system with a YMT-14 membrane (30kDa; Millipore Corp. Bredford, MA). A volume of $0.5 \mathrm{~mL}$ plasma was transferred in the micropartition system, centrifuged at $2.500 \mathrm{rpm}$ for 20 min at $20^{\circ} \mathrm{C}$ and stored at $-70^{\circ} \mathrm{C}$ until analyses. Analysis of platinum in ultrafiltrate were done using flameless atomic absorption spectrometry (SOLAAR MQZ Zeeman AAS, Thermo Optek), at Slotervaart Hospital, Amsterdam as described by van Warmerdam et al [18]. The lower limit of quantitation (LLQ) of the assay was $0.5 \mu \mathrm{mol} / \mathrm{L}$ with the accuracy of less than \pm $14.6 \%$ and the within- and between-day precision less than $\pm 7.9 \%$ and less than $\pm 7.7 \%$. A calibration curve platinum absorbance peak height versus carboplatin concentration in $10 \%$ ultrafiltrate was constructed and with a quadratic regression applied to the data. Concentrations of carboplatin in validation quality control samples were determined from the calibration curve and used to calculate accuracy and precision of the method within Excel (version 97, Microsoft). The measured AUC was estimated with the equation published by Sorensen et al. [17] as shown in Table 1. Predicted AUCs were calculated by the modified Calvert formula (administered carboplatin dose/ (predicted $\mathrm{CrCl}$ or $\mathrm{GFR}+25)$ ).

\section{Mathematical calculation of renal function prediction:}

Age, ethnicity and sex were recorded. Actual body weight, height, serum creatinine, -albumin, -urea and -cystatin $\mathrm{C}$ were measured. BSA was calculated using the equation of DuBois and DuBois [19] (Table 1). All patients had to collect urine over 24 hours for $\mathrm{CrCl}$ calculation before chemotherapy was started. The urine collections were compared with the last one and the difference have to be not greater than $10 \%$. Patients were precisely instructed 
by trained staff. $\mathrm{CrCl}$ and GFR estimates were calculated in $\mathrm{mL} / \mathrm{min}$ using the equations $[9-16,20]$ in Table 1.

Measurement of different blood and urine parameters:

Blood samples were drawn during the urine collection period or in outpatients immediately afterwards to assess serum creatinine, blood urea (BU), albumin (Alb) and cystatin C. Serum and urine creatinine were measured using an alkaline picrate-kinetic assay (Jaffé) [21]. The upper limit of the serum creatinine reference interval was $1.2 \mathrm{mg} / \mathrm{dL}$ in males and $0.9 \mathrm{mg} / \mathrm{dL}$ in females and the upper limit of urine creatinine was $200 \mathrm{mg} / \mathrm{dL}$ in our laboratory. BU was determined using an urease method and expressed in milligrams per deciliter. Alb was measured using a bromcresol green method and expressed in grams per decilitre [22]. The reference intervals were 12-46 mg/dL in BU and 3.4-4.8 $\mathrm{g} / \mathrm{dL}$ in Alb, respectively. Cystatin $\mathrm{C}$ was examined in serum samples with the $\mathrm{N}$ Latex Cystatin $\mathrm{C}$ test kit. The test represents particle-enhanced immunonephelometric method and was examined on a BN ProSpec analyser (Dade-Behring, Marburg, Germany) [23]. The reference interval for cystatin C was $0.57-0.96 \mathrm{mg} / \mathrm{L}$ in males and $0.50-0.96 \mathrm{mg} / \mathrm{L}$ in females.

Calculation of the carboplatin dose:

The administered carboplatin dose was calculated by a modified Calvert formula [5] whereas GFR was substituted by $\mathrm{CrCl}$ via 24-hour urine collection or calculated by Jelliffe [10] (Table 1). The target AUC was $5 \mathrm{mg} / \mathrm{mL}$ x min.

Statistical considerations:

A sample size of at least 25 patients had to be considered for statistical analysis. The performance of the prediction of the AUCs was evaluated using the mean percentage error (MPE \%, a measure of bias) and the mean absolute 
percentage error (MAPE \%, a measure of precision) by Bland-Altman [24]. MPE was calculated as the percentage difference between the predicted AUC for each $\mathrm{CrCl}$ or GFR equation and measured $\mathrm{AUC}$ as followed:

$M P E=\left[N^{-1} \times \sum^{N}{ }_{i=1}\left(p e_{i}\right)\right] \times 100$

MAPE $=\left[\mathrm{N}^{-1} \times \sum_{\mathrm{i}=1}^{\mathrm{N}}\left(\right.\right.$ Ipe $\left.\left._{\mathrm{i}} \mid\right)\right] \times 100$

where $\mathrm{N}$ is the number of patients (29) and pe is the relative prediction error for predicted carboplatin AUC and it is defined as follows (predicted AUC measured AUC) x100 /measured AUC.

An average bias close to zero was desirable. A positive bias indicated overestimation of carboplatin AUC and a negative bias indicated underestimation. The data are normally distributed, therefore statistical differences between measured and predicted carboplatin AUC were evaluated by t-test for paired samples. Results were considered to be statistically significant at $p<0.05$.

\section{Results}

\section{Carboplatin AUC}

29 patients (22 females and 7 males) were enrolled in the analysis. Specific patient demographics, carboplatin dose, carboplatin-AUC and estimations of renal functions are detailed in Table 3. The AUC predictions of carboplatin calculated by applying the formulas are summerized in Table 4 . The mean measured carboplatin was AUC $5.8 \mathrm{mg} / \mathrm{ml}$ x min (target AUC $5.0 \mathrm{mg} / \mathrm{ml}$ x min), the mean absolute administered carboplatin dose $498 \mathrm{mg}$, and the mean observed GFR (oGFR) was $63 \mathrm{~mL} / \mathrm{min}$. The bias (\%) and precision (\%) are displayed in Table 4. The MPE of carboplatin AUC was $+5 \%$ and - $5 \%$ for the 
Jelliffe and algorithm modified Calvert formula. The degree of bias was greater with the Cockcroft-Gault, Schmitt, Hoek, Chatelut and endogenous $\mathrm{CrCl}$ modified Calvert formula with the MPE being - $10 \%,-14 \%$, - $15 \%,-20 \%$, $25 \%$, respectively.

\section{GFR and $\mathrm{CrCl}$}

The mean oGFR was $63 \mathrm{~mL} / \mathrm{min}$. The Jelliffe and algorithm based renal calculation showed the lowest difference with a estimated $\mathrm{CrCl}(\mathrm{eCrCl})$ of 55 $\mathrm{mL} / \mathrm{min}$ and a estimated GFR (eGFR) of $68 \mathrm{~mL} / \mathrm{min}$. All other equations showed a higher difference.

\section{GFR and obesity}

Six from 29 patients were obese with a body mass index (BMI) greater $30 \mathrm{~kg} / \mathrm{m}^{2}$. Data are shown in table 5 . The mean oGFR of these patients was $68 \mathrm{~mL} / \mathrm{min}$. oGFR was overestimated $1 \%$ by the algorithm and was underestimated $3 \%$ by the Jelliffe formula. The degree of bias was greater for the Cockcroft-Gault formula and the $\mathrm{CrCl}$ via 24 -hour urine collection with the MPE being $+37 \%$ and $+39 \%$, respectively.

GFR and renal insufficiency

A oGFR with $22 \mathrm{~mL} / \mathrm{min}$ was shown by two patients. The novel algorithm revealed the closest values to the observed situation ( 30 and $40 \mathrm{~mL} / \mathrm{min}$ ), compared to other equations, including the often in clinical practice used formula by Jelliffe ( 51 and $50 \mathrm{~mL} / \mathrm{min}$ ).

\section{Discussion}


Several recommendations clearly indicate the need for dose modification of selected anticancer drugs in patients with renal dysfunction when these drugs are excreted primarily in unchanged or active form through the kidneys [25].

According to the IRMA-1 $(n=4684)$ and IRMA-2 $(n=4945)$ study results which were solely based on the MDRD equation, a high prevalence of renal dysfunction should be estimated in cancer patients, when about $38-41 \%$ and $11 \%$ of patients revealed GFR values $\left(\mathrm{mL} / \mathrm{min} / 1.73 \mathrm{~m}^{2}\right)$ between $60-89 \mathrm{~mL} / \mathrm{min}$ and $30-59 \mathrm{~mL} / \mathrm{min}$, respectively [26]. According to our study population these percentages may be even higher with $35 \%$ of patients being between $30-59$ $\mathrm{mL} / \mathrm{min}$, based on GFR calculation according to the Calvert formula and carboplatin AUC measurement as well as on our novel algorithm which is not solely based on the MDRD formula [14].

If one wants to translate the IRMA-1 and IRMA-2 study results as well as the GFR-adapted dose modifications into clinical practice, accurate assessment of the individual renal function in cancer patients will be mandatory [26]. The real situation of individual GFR is highly reflected by using radioisotopes (for example ${ }^{51} \mathrm{Cr}$-EDTA), however, this gold standard is limited by its invasive technique, high costs, varying regulatory approvals and need for specific expertise.

The estimation of GFR by the measurement of creatinine clearance $(\mathrm{CrCl})$ is a far more easy method, but needs intensified patient instruction and adherence to avoid inaccuracy and inconvenience during urine collection over 24 hours in our experience. Generally, the $\mathrm{CrCl}$-values overestimate GFR to some extent because of additional tubular creatinine secretion [27]. Finally, concomitant hydration of patients may bias $\mathrm{CrCl}$ measurement. 
As a consequence, a very broad spectrum of different formulas has been published with the ambitious aim to calculate renal function in different patient populations very easily and closely to the real GFR situation [28]. In this context, formulas revealing a mean percentage error of only $1 \%$ to $2 \%$ compared to clearance values based on radioisotope measurements were very encouraging. However, more detailed analysis have shown a well-known difficulty with most other equations used before, namely manifest overestimation and underestimation of the "real" situation in the GFR segments $<50 \mathrm{ml} / \mathrm{min}$ and $>100 \mathrm{ml} / \mathrm{min}$, respectively $[7,8]$. Based on the fact, that an overestimation of the constitutive GFR particularly in patients with renal dysfunction might result in a lower percentage of dose modifications than needed, the acceptance of novel formulas in clinical oncology remains a challenge. The same is true for the Chatelut formula, when reports about gender-dependent potential carboplatin under- and overdosing discouraged its further use [29]. Based on the well-known non-linearity of calculations over a broad range of GFR values, a novel algorithm has been recently presented by our study group based on 123 cancer patients with the aim to evaluate the probably best fitted formula for different GFR segments: $<45 \mathrm{~mL} / \mathrm{min}, 45-95$ $\mathrm{mL} / \mathrm{min}$ and $>95 \mathrm{~mL} / \mathrm{min}$ [14]. In our model, the 6-variable MDRD formula [11] resulted in an accurate estimation of GFR values between $45-95 \mathrm{~mL} / \mathrm{min}$, however, further calculations were needed by the modified Salazar-Corcoran formula [12] and the Wright-formula [13] in the lower and upper GFR-ranges for more appropriateness, respectively. In order to further validate the clinical usefulness of our novel algorithm, this analysis compared GFR calculated according to the Calvert formula [5] and measured carboplatin AUC, in order to compare it with different calculation methods and vice versa $[9-16,20]$. 
Carboplatin has been widely accepted as a "model substrate" to examine clinical pharmacokinetic correlations in more detail. First, carboplatin reflects a fairly simple clinical pharmacokinetic behaviour because about $75 \%$ of the applied dose are excreted in the urine whereas the remainder is primarily bound to different tissues from which it may be released very slowly over time $[1,5]$. Second, AUC values are clinically relevant and have been shown to correlate with the probability of response as well as the risk for severe forms of thrombocytopenia $[2,3]$. Third, AUC values can be measured in vivo without the need for multiple blood sampling [17,30]. According to the Calvert formula (carboplatin dose $=$ target AUC $\times$ [GFR +25$]$ [5], GFR can be calculated by the ratio, administered carboplatin dose/ measured AUC - 25.

Based on our study results the use of the MDRD formula may be favoured for cancer patients between $45-95 \mathrm{~mL} / \mathrm{min}$ which is in accordance to other study groups who found a closer correlation of MDRD-related estimates to measured ${ }^{125}$ I-iothalamate and aminoglycoside clearance than with other calculations particularly in patients with chronic kidney disease [31]. Conflicting data were primarily based on observational study results, referring on clinical end points (for example carboplatin-associated nadir of thrombocytopenia during early treatment cycles) rather than clinical-pharmacokinetic data.

Our study results revealed some further important information when we compared GFR assessment by the novel algorithm [14] based on carboplatin AUC measurements compared to other estimations $[9,10,15,16,20]$.

(1) In contrast to the algorithm-based values, most obese patients with a body mass index (BMI) ranging from 30.1 to $37.8 \mathrm{~kg} / \mathrm{m}^{2}$, GFR values calculated by 
the CG-formula were clearly overestimated, as well as $\mathrm{CrCl}$ via 24-hour urine collection.

(2) $\mathrm{CrCl}$ assessment via 24-hour-urine-collection can be associated with enormous deviations up to $138 \mathrm{~mL} / \mathrm{min}$ in individual patients, which may be related to bias via intensified hydration, whereas concomitant hydration did not have an impact on the results revealed by the novel algorithm.

(3) In two patients with oGFR values below $30 \mathrm{~mL} / \mathrm{min}$ (both $22 \mathrm{~mL} / \mathrm{min}$ ) the novel algorithm revealed the closest values to the measured situation (30 and $40 \mathrm{~mL} / \mathrm{min}$ ), compared to other equations, including the Jelliffe formula (51 and $50 \mathrm{~mL} / \mathrm{min})$.

(4) Compared to the Hoek formula which include cystatin C measurement as a further parameter to increase accuracy, we observed a lower mean percentage error (MPE) with the novel algorithm.

Although cystatin $\mathrm{C}$ may be a more sensitive marker than serum creatinine to assess individual GFR because of the neglectable role of gender, muscle mass or age-related factors, those results are primarily derived from healthy volunteers, whereas in cases of inflammation, concomitant application of prednisone and diabetes mellitus, deviations are highly probable to occur resulting in underestimation of GFR [27]. In addition, cancer patients may have an enhanced extracellular secretion of cysteine proteases in different tumor types which results in an increase of cystatin $\mathrm{C}$ accompanied by potential GFR overestimation [32].

Our suggestion to prefer the MDRD formula [11] rather than a cystatin C-based equation (for example Hoek formula) [15] in a broad spectrum of patients with 
GFR $>60 \mathrm{ml} / \mathrm{min} / 1.73 \mathrm{~m}^{2}$ is supported by the results of a comparative trial in former kidney donors when the MDRD equation revealed to be more accurate than the latter with iohexol GFR as a reference [33].

Based on these findings the enthusiasm was based on presentation of a universal formula for the calculation of carboplatin clearance [16] irrespective of the underlying body weight of the patient (for example $40-137 \mathrm{~kg}$ ) may have to be restrained. In our study population, the retrospective use of this universal formula did not result in closer values to carboplatin AUC based on the Calvert formula than our novel algorithm.

Though the concept to use the novel algorithm for accurate GFR calculation in clinical practice is clearly encouraged by the study results, there may be some limitations: first, one may argue that far more cancer patients may be needed to validate MPE (\%) and MAPE(\%) more extensively and, second, a correlation of GFR values revealed by radioisotope measurements rather than calculations via the modified Calvert formula and carboplatin AUC measurement may prove the practicability of the novel algorithm more tightly. Third, we used a limited sampling method which need a strictly controlled infusion duration and blood sampling points of each patient. Fourth, patients with special conditions, for example very low serum creatinine values, may need modified GFR estimation for example based on body cell mass, to improve dose individualization [34].

In conclusion, the presented study results based on carboplatin AUC measurements indicate that the concept to find one single formula to calculate accurately individual GFR values over a broad range of constitutive renal 
function may be less successful than an algorithm-based strategy which does not include cystatin $\mathrm{C}$ as a further parameter.

\section{Acknowledgements}

Karin Holweger is supported by an educational grant from Amgen Germany. 
Table 1. Pharmacokinetic of carboplatin - Estimation of carboplatin dose, carboplatin clearance, carboplatin AUC, BSA and estimation of renal function

Estimation of carboplatin dose:

Calvert [5]: $\quad$ Dose[mg] $=$ target-AUC[mg/mLxmin] $\times(G F R+25)[\mathrm{mL} / \mathrm{min}]$

Estimation of carboplatin clearance:

Chatelut [20]: $\quad$ Clearance $[\mathrm{mL} / \mathrm{min}]=0.134 \times$ weight $[\mathrm{kg}]+[218 \times$ weight $[\mathrm{kg}] \times(1-$ $0.00457 \times$ age[years $] \times(1-0.314 \times \mathrm{sex})] / \mathrm{SCr}[\mu \mathrm{mol} / \mathrm{L}]$

Schmitt [16]: Clearance $[\mathrm{mL} / \mathrm{min}]=$

$\left.117.8(\mathrm{SCr}[\mu \mathrm{mol} / \mathrm{L}] / 75)^{-0.450} \times(\mathrm{cysC}[\mathrm{mg} / \mathrm{L}]] / 1.00\right)^{-0.385} \times$

$(\text { weight }[\mathrm{kg}] / 65)^{+0.504} \times(\text { age[years] } / 56)^{-0.366} \times 0.847^{\text {sex }}$

Estimation of carboplatin AUC:

Sorensen [17]: $\quad A U C[\mathrm{mg} / \mathrm{mLxmin}]=0.053 \times \mathrm{C}_{0.25 h}[\mathrm{mg} / \mathrm{L}]+0.401 \times \mathrm{C}_{2.75 h}[\mathrm{mg} / \mathrm{L}]$ $+0.628$

Estimation of BSA:

DuBois [19]: $\quad$ BSA $\left[\mathrm{m}^{2}\right]=0.007184 \times$ weight $[\mathrm{kg}]^{0.425} \times$ height $[\mathrm{cm}]^{0.725}$

Estimation of renal function:

oGFR: GFR $[\mathrm{mL} / \mathrm{min}]=$ (administered dose[mg] $/$ measuredAUC[mg/mLxmin]) $-25 \mathrm{~mL} / \mathrm{min}$

Endogenous $\quad \mathrm{CrCl}[\mathrm{ml} / \mathrm{min}]=\frac{\mathrm{UCr}[\mathrm{mg} / \mathrm{dL}] \times \mathrm{V}[\mathrm{mL}]}{\mathrm{SCr}[\mathrm{mg} / \mathrm{dL}] \times \mathrm{T}[\mathrm{min}]}$

$\mathrm{CrCl}$ :

Cockcroft- $\quad \mathrm{CrCl}[\mathrm{mL} / \mathrm{min}]=\frac{[(140-\text { age }[\text { years }]) \times(\text { weight }[\mathrm{kg}])]}{72 \times \mathrm{SCr}[\mathrm{mg} / \mathrm{dL}]} \times \operatorname{sex}$

Gault [9]: 
Jelliffe [10]: $\quad \operatorname{CrCl}[\mathrm{mL} / \mathrm{min}]=\frac{\{98-0.8 \times(\text { age }[\text { years }]-20)\}}{\mathrm{SCr}[\mathrm{mg} / \mathrm{dL}]} \times\left(\frac{\mathrm{BSA}\left[\mathrm{m}^{2}\right]}{1.73\left[\mathrm{~m}^{2}\right]}\right) \times \operatorname{sex}$

Hoek [15]: $\quad$ GFR $[\mathrm{mL} / \mathrm{min}]=\left(-4.32+80.35 \times \frac{1}{\mathrm{Cys}[\mathrm{mg} / \mathrm{L}]}\right) \times\left(\frac{\mathrm{BSA}\left[\mathrm{m}^{2}\right]}{1.73\left[\mathrm{~m}^{2}\right]}\right)$
Algorithm [14]
(Figure1)
MDRD [11]:

$$
\begin{aligned}
\mathrm{GFR}[\mathrm{mL} / \mathrm{min}]= & 170 \times[\mathrm{SCr}[\mathrm{mg} / \mathrm{dL}]]^{-0.999} \times[\text { age }[\text { years }]]^{-0.176} \times[\text { ethnicity }] \times[\mathrm{BU}[\mathrm{mg} / \mathrm{dL}]]^{-0.170} \\
& \times\left[\text { Alb }[\mathrm{g} / \mathrm{dL}]^{+0.318} \times\left(\frac{\mathrm{BSA}\left[\mathrm{m}^{2}\right]}{1.73\left[\mathrm{~m}^{2}\right]}\right)\right.
\end{aligned}
$$

$M D R D<45 \mathrm{~mL} / \mathrm{min}:$

modified Males:

Salazar- $\quad \operatorname{CrCl}[\mathrm{mL} / \mathrm{min}]=\frac{(137-\text { age }[\text { years }]) \times\left\{(0.285 \times \text { weight }[\mathrm{kg}])+\left[12.1 \times\left(\mathrm{BSA}\left[\mathrm{m}^{2}\right]\right)\right]\right\}}{(51 \times \operatorname{SCr}[\mathrm{mg} / \mathrm{dL}])}$ Corcoran [12]:

Females:

$\mathrm{CrCl}[\mathrm{mL} / \mathrm{min}]=\frac{(146-\text { age }[\text { years }]) \times\left\{(0.287 \times \text { weight }[\mathrm{kg}])+\left[9.74 \times\left(\mathrm{BSA}\left[\mathrm{m}^{2}\right]\right)\right]\right\}}{(60 \times \mathrm{SCr}[\mathrm{mg} / \mathrm{dL}])}$

$M D R D>95 \mathrm{~mL} / \mathrm{min}:$

Wright [13]: $\quad$ GFR $[\mathrm{mL} / \mathrm{min}]=\frac{(6580-38.8 \times \text { age }[\text { years }]) \times \mathrm{BSA}\left[\mathrm{m}^{2}\right] \times(\text { sex })}{\mathrm{SCr}[\mu \mathrm{mol} / \mathrm{L}]}$

$\mathrm{Alb}=$ serum albumin; $\mathrm{BSA}=$ body surface area; $\mathrm{BU}=\mathrm{blood}$ urea; $\mathrm{CrCl}=$ creatinine clearance; CysC=cystatin C; GFR=glomerular filtration rate; $h=$ hour; $M D R D=$ modification of diet in renal disease; oGFR=observed glomerular filtration rate; $\mathrm{SCr}=$ serum creatinine; $\mathrm{T}=$ time of urine collection; $\mathrm{UCr}=$ urine creatinine; $\mathrm{V}=$ volume of urine after $24 \mathrm{~h}$.

Sex: Chatelut and Schmitt male 0 female 1.0 other equations male 1.0; female Cockcroft-Gault 0.85; Jelliffe 0.9; MDRD 0.762; Wright 0.832. The MDRD formula considers the factor 1.0 if patients are white and 1.180 if patients are black. 
Table 2. Chemotherapy regimen, infusion duration, sampling time points, administered carboplatin dose and measured carboplatin -AUC for each patient.

\begin{tabular}{|c|c|c|c|c|c|c|c|}
\hline $\mathrm{Nr}$ & Sex & Chemotherapy & $\begin{array}{l}\text { Infusion duration (start, } \\
\text { end at) }\end{array}$ & $\begin{array}{l}\text { Sampling } \\
\text { point } \\
0.25 \mathrm{~h}\end{array}$ & $\begin{array}{l}\text { Sampling } \\
\text { point } \\
2.75 \mathrm{~h}\end{array}$ & $\begin{array}{l}\text { Administered } \\
\text { carboplatin } \\
\text { dose [mg] }\end{array}$ & $\begin{array}{l}\text { Measured } \\
\text { carboplatin AUC } \\
{[\mathrm{mg} / \mathrm{ml} \times \mathrm{min}]}\end{array}$ \\
\hline 1 & $\mathrm{M}$ & Vinorelbine & $1: 05$ h (10.12 - 11.17) & 11.32 & 14.02 & 600 & 4.5 \\
\hline 4 & $\mathrm{~F}$ & Pemetrexed & $1: 00$ h $(12.28-13.28)$ & 13.43 & 16.13 & 385 & 5.2 \\
\hline 5 & $\mathrm{~F}$ & Gemcitabine & $1: 00$ h $(10.48-11.48)$ & 12.03 & 14.33 & 350 & 6.0 \\
\hline 6 & $M$ & Paclitaxel & $1: 00$ h (12.55 - 13.55) & 14.10 & 16.40 & 500 & 6.0 \\
\hline 8 & $\mathrm{~F}$ & Paclitaxel & $1: 00$ h (11.35 - 12.35) & 12.50 & 15.20 & 390 & 5.6 \\
\hline 9 & $M$ & Paclitaxel/Etoposide & $1: 00$ h $(12.25-13.25)$ & 13.40 & 15.10 & 995 & 5.7 \\
\hline 10 & $\mathrm{~F}$ & Paclitaxel/Trastuzumab & $1: 00$ h $(10.35-11.35)$ & 11.50 & 14.20 & 515 & 6.1 \\
\hline 12 & $M$ & Etoposid & $1: 05$ h $(11.13-12.18)$ & 12.33 & 15.03 & 650 & 4.8 \\
\hline 13 & $\mathrm{~F}$ & Paclitaxel & $1: 05$ h (10.30 - 11.35) & 11.50 & 14.20 & 517 & 5.2 \\
\hline 14 & $\mathrm{~F}$ & Paclitaxel & $1: 05$ h (10.45 - 11.50) & 12.05 & 14.35 & 568 & 6.6 \\
\hline 15 & $\mathrm{~F}$ & Paclitaxel & $1: 00$ h $(12.15-13.15)$ & 13.30 & 16.00 & 456 & 7.1 \\
\hline 16 & $\mathrm{~F}$ & Paclitaxel/Trastuzumab & $1: 00$ h $(10.35-11.35)$ & 11.50 & 14.20 & 454 & 5.9 \\
\hline 17 & $\mathrm{~F}$ & Paclitaxel & $1: 00$ h $(10.45-11.45)$ & 12.00 & 14.30 & 484 & 6.6 \\
\hline 19 & $\mathrm{~F}$ & Paclitaxel & $1: 00$ h $(10.50-11.50)$ & 12.05 & 14.35 & 406 & 6.7 \\
\hline 21 & $\mathrm{~F}$ & Paclitaxel & $1: 00$ h $(10.30-11.30)$ & 11.45 & 14.15 & 519 & 7.5 \\
\hline 22 & $M$ & Etoposide & $1: 00$ h $(11.15-12.15)$ & 12.30 & 15.00 & 600 & 5.8 \\
\hline 23 & $\mathrm{~F}$ & Paclitaxel & $1: 00$ h $(10.30-11.30)$ & 11.45 & 14.15 & 555 & 5.8 \\
\hline 24 & $\mathrm{~F}$ & Paclitaxel & $1: 00$ h $(12.00-13.00)$ & 13.15 & 15.45 & 480 & 5.3 \\
\hline 25 & $\mathrm{~F}$ & Paclitaxel & $1: 00$ h $(10.30-11.30)$ & 11.45 & 14.15 & 311 & 5.8 \\
\hline 29 & $\mathrm{~F}$ & Paclitaxel & $1: 00$ h $(12.00-13.00)$ & 13.15 & 15.45 & 560 & 5.1 \\
\hline 30 & $\mathrm{~F}$ & Paclitaxel & $1: 00$ h $(10.30-11.30)$ & 11.45 & 14.15 & 574 & 4.8 \\
\hline 31 & $\mathrm{~F}$ & Paclitaxel & $1: 00 \mathrm{~h}(10.50-11.50)$ & 12.05 & 14.35 & 482 & 4.2 \\
\hline 32 & $\mathrm{M}$ & Gemcitabine & $1: 00$ h $(10.30-11.30)$ & 11.45 & 14.15 & 575 & 4.4 \\
\hline
\end{tabular}




\begin{tabular}{|c|c|c|c|c|c|c|c|}
\hline 34 & $\mathrm{M}$ & Etoposide & $1: 02$ h (12.10 - 13.12) & 13.27 & 15.57 & 500 & 6.7 \\
\hline 35 & $\mathrm{~F}$ & Paclitaxel & $1: 00$ h $(11.10-12.10)$ & 12.25 & 14.55 & 465 & 8.0 \\
\hline 36 & $\mathrm{~F}$ & Paclitaxel & $1: 00$ h $(11.30-12.30)$ & 12.45 & 15.15 & 375 & 5.7 \\
\hline 38 & $\mathrm{~F}$ & Paclitaxel & $1: 00$ h $(11.15-12.15)$ & 12.30 & 15.00 & 355 & 4.4 \\
\hline 39 & $\mathrm{~F}$ & Etoposide & $1: 00 \mathrm{~h}(11.10-12.10)$ & 12.25 & 14.55 & 470 & 6.7 \\
\hline 40 & $\mathrm{~F}$ & Etoposide & $1: 00 \mathrm{~h}(11.20-12.20)$ & 12.35 & 15.05 & 450 & 5.2 \\
\hline
\end{tabular}

$\mathrm{AUC}=$ area under the concentration time curve; $\mathrm{Nr}=$ number of patient. 
Table 3. Patients` characteristics, administered carboplatin dose, -AUC, and observed and estimated renal function.

\begin{tabular}{lc}
\hline Demographic & Patients $(\mathrm{n}=29)$ \\
& Mean \pm SD \\
\hline Age (years) & $61.0 \pm 9.0$ \\
Weight $(\mathrm{kg})$ & $70.5 \pm 15.0$ \\
Height $(\mathrm{cm})$ & $167.9 \pm 8.0$ \\
BSA $\left(\mathrm{m}^{2}\right)$ & $1.79 \pm 0.19$
\end{tabular}

Carboplatin dose $(\mathrm{mg})$ :

administered

$498 \pm 97$

Carboplatin AUC (mg/mL x min):

Target AUC

Measured AUC

$5.8 \pm 1.0$

Renal function estimations ( $\mathrm{mL} / \mathrm{min})$ :

oGFR (observed GFR)

$63 \pm 20$

eGFR (Algorithm)

$68 \pm 18$

eCrCl (Jelliffe)

$60 \pm 14$

eCrCl (Cockcroft-Gault)

$75 \pm 23$

eGFR (Hoek)

$79 \pm 23$

eCrCl (24-hour urine collection)

$82 \pm 30$

$\mathrm{AUC}=$ area under the concentration time curve, $\mathrm{BSA}=$ body surface area; $\mathrm{CrCl}=\mathrm{creatinine}$ clearance; eCrCl=estimated creatinine clearance; eGFR=estimated glomerular filtration rate; oGFR= observed glomerular filtration rate; $\mathrm{n}=$ number; $\mathrm{SD}=$ standard deviation . 
Table 4. Measured carboplatin AUC (mg/mL x min) and predicted AUC by using the modified Calvert formula with estimations of renal function and administered carboplatin dose. Bias and precision between carboplatin AUC predictions and measured carboplatin AUC.

\begin{tabular}{lccc}
\hline Formula & AUC \pm SD & MPE \pm SD & MAPE \pm SD \\
\cline { 2 - 3 } & mg/mL x min & $\%$ \\
\hline Measured AUC & $5.8 \pm 1.0$ & $-5 \pm 17$ & $15 \pm 10$ \\
AUC - Calvert (Algorithm) & $5.4 \pm 1.0$ & $+5 \pm 20$ & $16 \pm 13$ \\
AUC - Calvert (Jelliffe) & $5.9 \pm 0.8$ & $-10 \pm 17$ & $17 \pm 10$ \\
AUC - Calvert (Cockcroft-Gault) & $5.1 \pm 0.9$ & $-15 \pm 11$ & $17 \pm 9$ \\
AUC - Calvert (Hoek) & $4.9 \pm 0.8$ & $-25 \pm 35$ & $31 \pm 30$ \\
AUC - Calvert (24-hour urine collection) & $4.8 \pm 1.1$ & $-20 \pm 17$ & $24 \pm 11$ \\
AUC - Chatelut & $4.6 \pm 0.8$ & $-14 \pm 12$ & $16 \pm 8$ \\
AUC - Schmitt & $4.9 \pm 0.7$ & &
\end{tabular}

$\overline{\mathrm{AUC}}=$ area under the concentration time curve; MAPE=mean absolute percentage error; MPE=mean percentage error; $\mathrm{n}=$ number of patients; $\mathrm{SD}=\mathrm{standard}$ deviation. 
Table 5. Observed and estimated GFR or $\mathrm{CrCl}$ and AUC values in obese patients (1-6) and patients with renal insufficiency (7-8).

\begin{tabular}{|c|c|c|c|c|c|c|c|c|c|c|c|c|c|}
\hline $\mathrm{Nr}$ & Sex & $\begin{array}{l}\text { Age } \\
\text { [years] }\end{array}$ & $\begin{array}{l}\text { Weight } \\
{[\mathrm{kg}]}\end{array}$ & $\begin{array}{l}\mathrm{BMI} \\
{\left[\mathrm{kg} / \mathrm{m}^{2}\right]}\end{array}$ & $\begin{array}{l}\mathrm{SCr} \\
{[\mu \mathrm{mol}]}\end{array}$ & $\begin{array}{l}\text { CysC } \\
{[\mathrm{mg} / \mathrm{L}]}\end{array}$ & $\begin{array}{l}\text { Dose } \\
\text { administered } \\
{[\mathrm{mg}]}\end{array}$ & $\begin{array}{l}\text { AUC } \\
\text { measured } \\
{[\mathrm{mg} / \mathrm{ml} \times \mathrm{min}]}\end{array}$ & $\begin{array}{l}\text { oGFR } \\
{[\mathrm{mL} / \mathrm{min}]}\end{array}$ & $\begin{array}{l}\text { eGFR } \\
\text { (Algor) } \\
{[\mathrm{mL} / \mathrm{min}]}\end{array}$ & $\begin{array}{l}\mathrm{eCrCl} \\
(\mathrm{CG}) \\
{[\mathrm{mL} / \mathrm{min}]}\end{array}$ & $\begin{array}{l}\mathrm{eCrCl} \\
\text { (Jelliffe) } \\
{[\mathrm{mL} / \mathrm{min}]}\end{array}$ & $\begin{array}{l}\mathrm{eCrCl}(24 \\
\text { hour urine }) \\
{[\mathrm{mL} / \mathrm{min}]}\end{array}$ \\
\hline 1 & $\mathrm{~F}$ & 69 & 90.2 & 36.1 & 98 & 1.09 & 390 & 5.2 & 51 & 51 & 69 & 62 & 60 \\
\hline 2 & $F$ & 65 & 84.0 & 30.5 & 80 & 1.06 & 517 & 5.6 & 68 & 65 & 83 & 58 & 71 \\
\hline 3 & $F$ & 57 & 78.6 & 30.7 & 80 & 0.76 & 568 & 6.0 & 69 & 48 & 56 & 59 & 72 \\
\hline 4 & $\mathrm{~F}$ & 56 & 89.9 & 33.4 & 71 & 0.93 & 555 & 6.0 & 67 & 85 & 111 & 63 & 92 \\
\hline 5 & $\mathrm{~F}$ & 47 & 102.8 & 37.8 & 80 & 0.83 & 482 & 4.5 & 81 & 81 & 125 & 80 & 133 \\
\hline 6 & $F$ & 53 & 90.0 & 30.1 & 71 & 0.86 & 550 & 5.7 & 71 & 81 & 115 & 69 & 148 \\
\hline mean & & 58 & 89.3 & 33.1 & 80 & 0.92 & 510 & 5.5 & 68 & 69 & 93 & 65 & 96 \\
\hline SD & & 8 & 8.0 & 3.3 & 10 & 0.13 & 67 & 0.6 & 10 & 16 & 28 & 8 & 37 \\
\hline $\begin{array}{c}\text { MPE } \\
\%\end{array}$ & & & & & & & & & & +1 & +37 & -3 & +39 \\
\hline MAPE & & & & & & & & & & 13 & 43 & 10 & +39 \\
\hline$\%$ & & & & & & & & & & & & & \\
\hline 7 & $\mathrm{~F}$ & 72 & 50.0 & 17.7 & 106 & 1.69 & 311 & 6.7 & 22 & 30 & 33 & 51 & 42 \\
\hline 8 & $F$ & 67 & 53.6 & 19.9 & 88 & 1.71 & 375 & 8.0 & 22 & 40 & 46 & 50 & 42 \\
\hline
\end{tabular}

Algor=algorithmus; $\mathrm{AUC}=$ area under the concentration time curve; $\mathrm{BMl}=$ body mass index; $\mathrm{CG}=\mathrm{Cockcroft}-\mathrm{Gault}$; eCrCl=estimated creatinine clearance; CysC=cystatin C; $\mathrm{F}=$ female; eGFR=estimated glomerular filtration rate; oGFR=observed glomerular filtration rate; $\mathrm{Nr}=$ number; $\mathrm{SCr}=\mathrm{serum}$ creatinine. 
Figure 1. Algorithm for accurate $\mathrm{CrCl}$ or GFR-estimation [14]. 
References

1. Calvert AH, Harland SJ, Newell DR, Siddik ZH, Jones AC, McElwain TJ, Raju S, Wiltshaw E, Smith IE, Baker JM, Peckham MJ, Harrap KR (1982) Early clinical studies with cis-diammine-1,1-cyclobutane dicarboxylate platinum II. Cancer Chemother Pharmacol 9: 140-147

2. Egorin MJ, Van Echo DA, Tipping SJ, OIman EA, Whitacre MY, Thompson BW, Aisner J (1984) Pharmacokinetics and dosage reduction of cis-diammine(1,1cyclobutanedicarboxylato)platinum in patients with impaired renal function. Cancer Res 44: 5432-5438

3. Jodrell DI, Egorin MJ, Canetta RM, Langenberg P, Goldbloom EP, Burroughs JN, Goodlow JL, Tan S, Wiltshaw E (1992) Relationships between carboplatin exposure and tumor response and toxicity in patients with ovarian cancer. $\mathrm{J}$ Clin Oncol 10: 520-528

4. Reyno LM, Egorin MJ, Canetta RM, Jodrell DI, Swenerton KD, Pater JL, Burroughs JN, Novak MJ, Sridhara R (1993) Impact of cyclophosphamide on relationships between carboplatin exposure and response or toxicity when used in the treatment of advanced ovarian cancer. J Clin Oncol 11: 1156-1164

5. Calvert AH, Newell DR, Gumbrell LA, O'Reilly S, Burnell M, Boxall FE, Siddik ZH, Judson IR, Gore ME, Wiltshaw E (1989) Carboplatin dosage: prospective evaluation of a simple formula based on renal function. J Clin Oncol 7: 17481756 
6. Calvert AH, Boddy A, Bailey NP, Siddiqui N, Humphreys A, Hughes A, Robson L, Gumbrell L, Thomas H, Chapman F, . (1995) Carboplatin in combination with paclitaxel in advanced ovarian cancer: dose determination and pharmacokinetic and pharmacodynamic interactions. Semin Oncol 22: 91-98

7. Marx GM, Blake GM, Galani E, Steer CB, Harper SE, Adamson KL, Bailey DL, Harper PG (2004) Evaluation of the Cockroft-Gault, Jelliffe and Wright formulae in estimating renal function in elderly cancer patients. Ann Oncol 15: 291-295

8. Poole SG, Dooley MJ, Rischin D (2002) A comparison of bedside renal function estimates and measured glomerular filtration rate (Tc99mDTPA clearance) in cancer patients. Ann Oncol 13: 949-955

9. Cockcroft DW, Gault MH (1976) Prediction of creatinine clearance from serum creatinine. Nephron 16: 31-41

10. Jelliffe RW (1973) Letter: Creatinine clearance: bedside estimate. Ann Intern Med 79: 604-605

11. Levey AS, Bosch JP, Lewis JB, Greene T, Rogers N, Roth D (1999) A more accurate method to estimate glomerular filtration rate from serum creatinine: a new prediction equation. Modification of Diet in Renal Disease Study Group. Ann Intern Med 130: 461-470

12. Salazar DE, Corcoran GB (1988) Predicting creatinine clearance and renal drug clearance in obese patients from estimated fat-free body mass. Am J Med 84: 1053-1060 
13. Wright JG, Boddy AV, Highley M, Fenwick J, McGill A, Calvert AH (2001) Estimation of glomerular filtration rate in cancer patients. Br J Cancer 84: 452459

14. Holweger K, Lipp HP, Dietz K, Hartmann JT, Bokemeyer C (2008) Novel algorithm for more accurate calculation of renal function in adults with cancer. Ann Pharmacother 42: 1749-1757

15. Hoek FJ, Kemperman FA, Krediet RT (2003) A comparison between cystatin C, plasma creatinine and the Cockcroft and Gault formula for the estimation of glomerular filtration rate. Nephrol Dial Transplant 18: 2024-2031

16. Schmitt A, Gladieff L, Lansiaux A, Bobin-Dubigeon C, Etienne-Grimaldi MC, Boisdron-Celle M, Serre-Debauvais F, Pinguet F, Floquet A, Billaud E, Le Guellec C, Penel N, Campone M, Largillier R, Capitain O, Fabbro M, Houede N, Medioni J, Bougnoux P, Lochon I, Chatelut E (2009) A universal formula based on cystatin $\mathrm{C}$ to perform individual dosing of carboplatin in normal weight, underweight, and obese patients. Clin Cancer Res 15: 3633-3639

17. Sorensen BT, Stromgren A, Jakobsen P, Jakobsen A (1993) A limited sampling method for estimation of the carboplatin area under the curve. Cancer Chemother Pharmacol 31: 324-327

18. van Warmerdam L.J.C., van Tellingen O., Maes R.A.A., Beijnen J.H. (1995) Validated method for the determination of carboplatin in biological fluids by Zeeman atomic absorption spectrometry. Fresenius J Anal Chem 351: 777-781

19. Du BD, Du Bois EF (1919) A formula to estimate the approximate surface area if height and weight be known. 1916. Nutrition 5: 303-311 
20. Chatelut E, Dezeuze A, Lavit M, Chevreau C, Pujol A, Boneu A, Roche H, Houin G, Bugat R, Canal P (1995) Prediction of carboplatin clearance from morphological and biological patient characteristics. Bull Cancer 82: 946-953

21. Perrone RD, Madias NE, Levey AS (1992) Serum creatinine as an index of renal function: new insights into old concepts. Clin Chem 38: 1933-1953

22. Corcoran RM, Durnan SM (1977) Albumin determination by a modified bromcresol green method. Clin Chem 23: 765-766

23. Finney H, Newman DJ, Gruber W, Merle P, Price CP (1997) Initial evaluation of cystatin $\mathrm{C}$ measurement by particle-enhanced immunonephelometry on the Behring nephelometer systems (BNA, BN II). Clin Chem 43: 1016-1022

24. Bland JM, Altman DG (1986) Statistical methods for assessing agreement between two methods of clinical measurement. Lancet 1: 307-310

25. Lichtman SM, Wildiers H, Launay-Vacher V, Steer C, Chatelut E, Aapro M (2007) International Society of Geriatric Oncology (SIOG) recommendations for the adjustment of dosing in elderly cancer patients with renal insufficiency. Eur $\mathrm{J}$ Cancer 43: 14-34

26. Launay-Vacher V, Oudard S, Janus N, Gligorov J, Pourrat X, Rixe O, Morere JF, Beuzeboc P, Deray G (2007) Prevalence of Renal Insufficiency in cancer patients and implications for anticancer drug management: the renal insufficiency and anticancer medications (IRMA) study. Cancer 110: 1376-1384

27. Stevens LA, Coresh J, Greene T, Levey AS (2006) Assessing kidney function-measured and estimated glomerular filtration rate. N Engl J Med 354: 24732483 
28. Holweger K, Bokemeyer C, Lipp HP (2005) Accurate measurement of individual glomerular filtration rate in cancer patients: an ongoing challenge. J Cancer Res Clin Oncol 131: 559-567

29. Dooley MJ, Poole SG, Rischin D, Webster LK (2002) Carboplatin dosing: gender bias and inaccurate estimates of glomerular filtration rate. Eur J Cancer 38: $44-51$

30. Ekhart Corine, de Jonge Milly E, Huitema Alwin DR, Schellens Jan HM, Rodenhuis Sjoerd, Beijnen Jos H (2006) Flat dosing of carboplatin is justified in adult patients with normal renal function. Clin Cancer Res 12: 6502-6508

31. Bookstaver PB, Johnson JW, McCoy TP, Stewart D, Williamson JC (2008) Modification of Diet in Renal Disease and modified Cockcroft-Gault formulas in predicting aminoglycoside elimination. Ann Pharmacother 42: 1758-1765

32. Kos J, Stabuc B, Cimerman N, Brunner N (1998) Serum cystatin C, a new marker of glomerular filtration rate, is increased during malignant progression. Clin Chem 44: 2556-2557

33. Louvar DW, Rogers TB, Bailey RF, Matas AJ, Ibrahim HN (2007) Cystatin C is not superior to creatinine-based models in estimating glomerular filtration rate in former kidney donors. Transplantation 84: 1112-1117

34. Donadio C, Lucchesi A, Ardini M, Cosio S, Fanucchi A, Gadducci A (2009) Dose individualization can minimize nephrotoxicity due to carboplatin therapy in patients with ovarian cancer. Ther Drug Monit 31: 63-69 